\title{
Impact of Corporate Social Responsibility on Organisational Effectiveness: An Empirical Analysis of Oil and Gas Industryin the Niger Delta, Nigeria
}

\author{
${ }^{1}$ Ukpabi, D.C., ${ }^{1}$ Ikaba, Y.V., ${ }^{2}$ Enyindah, C.W. ${ }^{1}$ Orji, O.G. $\&{ }^{3}$ Idatoru, A.R. \\ ${ }^{I}$ Marketing Department, Rivers State Polytechnic, Bori \\ ${ }^{2}$ Business Administration and Management Department, Rivers State Polytechnic, Bori \\ ${ }^{3}$ Accountancy Department, Rivers State Polytechnic, Bori
}

\begin{abstract}
Managers have come to terms with the pertinence and essentiality of the strategic andpregnable tool of CSR in the attainment of organisational goals. This study empirically investigates the role of CSR in the attainment of organisational goals in the oil and gas industry of Niger Delta of Nigeria.The result is intended to educate managers and players in the oil and gas industry of the enhanced form of carrying out CSR and its impact on the attainment of organisational effectiveness. The SPSS 21 was used. The statistical tools employed in the analysis were descriptive statistics, Pearson's Correlation and regression. A survey of 126 oil and gas firms revealed that $81.7 \%$ are engaged in CSR while $18.3 \%$ are not. The study also revealed that there is a significant correlation between CSR and organisational effectiveness. The results also indicate that a firm's active involvement in CSR has a significant contribution toits productivity and stability. Based on these findings, oil and gas firms should upscale their involvement in CSR by making a paradigm shift from the traditional donation of foodstuff and Christmas gifts to creating capacity that will engender independent entrepreneurial abilities, economic vision, passion and drive for self-accomplishment.
\end{abstract}

Key words:Corporate Social Responsibility, organisational effectiveness, productivity, stability.

\section{Introduction}

The practice of Corporate Social Responsibility (CSR) is now a global phenomenon. There is a growing need for firms operating in various communities to have a great deal of harmony with their host communities. This is particularly so in the Niger Delta region of Nigeria. This practice of ensuring that divergent needs of the host communities are reasonably attained in order to ensure smooth and harmonious operations is coined as corporate social responsibility [1]. This phenomenon is not only nationally accepted but it is globally practised. Globally, there is an enhance need for corporate manager to build new relationship between business and the natural (physical) environment as a means of mitigating the impacts of the past abuses (ill practices) on the environment [2].

Corporate Social Responsibility is the transparent business practices that are based on ethical values, compliance with legal requirements and respect for people - communities and the environment [3].Contemporarily, CSR is a concept whereby business organisations consider the interest of society by taking responsibility for the impact of their activities on customers, suppliers, employees, shareholders, communities and other shareholders as well as the environment [2]. While CSR is practiced by corporate bodies, it is imperative to evaluate its contributions to the attainment of organisational effectiveness.

A plethora of studies have found a correlation between social environmental performance and financial performance [4;5]. 6 suggests that a company's explicit costs are opposite of the hidden costs of the stakeholders. This assertion is made from the perspective of cost avoidance to major stakeholder and considering their satisfaction. Drawing from the stakeholders theory [7], the manager must satisfy a variety of constituents (e.g. investors and shareholders, employees, customers, suppliers, government and local community organisations) who can influence firm's outcomes.This study objective is to investigate, if there exists a correlation between CSR involvement by Nigerian oil and gas firms and organisational effectiveness. This paper is divided into section one - introduction;section two - literature review;section three - materials and methods while section four deals with the results, and study implications.

\section{Literature Review}

5 define corporate social responsibility as the "economic, legal and discretionary expectations that society has for organisations at a given point in time." For several decades, studies have investigated potential benefits that may be achieved by business that defined their responsibility as extending beyond the narrow perspective of maximizing profit [8]. [8]posit that some shareholders regard corporate social responsibility as a symbolic skill. [8]further argue that CSR is a symbol of reputation and a company's reputation will be improved 
by actions to support the community, resulting in positive influence on operators. Hence, when a company increases its costs by improving CSR, it gains competitive advantages.[5]assert that there is a positive relationship between corporate social responsibility and organizational effectiveness. Their findings reveal that involvement in social responsibility is one of the determinants of organizational effectiveness. They also contend that being socially responsible can aid organisations to succeed, increase profit and overall performance.

\subsection{CSR and Organisational Productivity}

It is contended that the productivity of an organization can be measured by the organisation being able to meet the expectation of the consuming public. This can be in terms of the quality of the products, timeliness of the production of expected products and the quantity of such products by the organization [5]. The attainment of optimal production is also measured by the organisation's ability to maximize the use of its financial resources $[9 ; 10]$. Even in the face of CSR, the organisation's financial resources must be maximally utilized in order to enhance organizational productivity [2].Organisations have short and long run plans. Organisational effectiveness is not necessarily measured in the firm's attainment of short run plans but in the attainment of its long run plans which contributes to the sustainability of firms [11]. [12]suggests that it is imperative for organisations to utilize the benefit of information technology in its operations. This will assist the firm in attaining maximal productivity. When firm's engage in CSR, unnecessary host community interference through complaints of marginalization in terms of employment allocation will be reduced [13]. This has a way of engendering continuity and stability in the firm's operations which underpins it productivity. It is therefore hypothesized that:

\section{H1: Perceived CSR is significantly related to organizational productivity}

\subsection{CSR and Organisational Stability}

[17]contend that if firms design strategic CSR, it will impact positively on new market opportunities that have related with firm's performance. Also, these activities affect the reputation of organisations and enhanced reputation is with financial performance and organizational stability [12;14]. [15]argue that firms that pursue CSR as a strategic objective are better performing in quality of products and services (QPS), effectiveness in doing business globally (BG), innovativeness[I], corporate culture (CC) and ethical obligations (EO), than the none CSR-compliant firms. It is contended that the stability of organisations can be enhanced through the good retention of its staff (employees) which see themselves are stakeholders in the organization [16].

Social responsibility is designed to meet all the criteria of social performance. Therefore, managers taking a proactive approach to embrace the need to behave in socially responsible ways to learn about the needs of different stakeholders and are willing to utilize organizational resources to pursue the interest of the stakeholders [17]. Considering the longrun growth and sustainable development following the norms of CSR, devising new policies and effective implementation is inevitable in bringing out and sustaining a balance between corporate world and society present generation and upcoming generation, man and nature [1]. It is imperative for as part of CSR to maintain a profile that is deemed good from time to time. This will aid in the attainment of sustainability of organisations. It is therefore hypothesized that:

H2: Perceived CSR is significantly related to organizational stability.

The model in Fig. 1 examines the relationship between Corporate Social Responsibility (CSR) and organisational effectiveness. Organisational effectiveness was measured with two variables - productivity and stability. It proposes that when a firm performs CSR, it will impact of its productivity and stability.

Organisational effectiveness

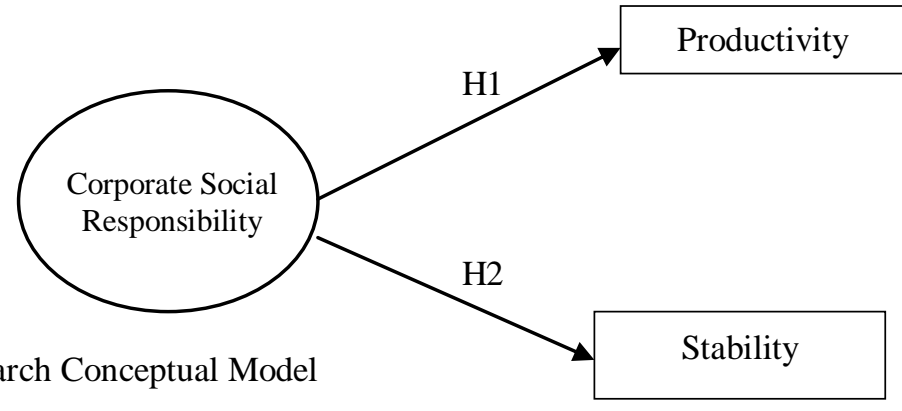

Figure 1 Research Conceptual Model 


\subsection{Population, Sample, Sampling and procedure}

\section{Materials and Methods}

The population for the study comprised oil and gas firms operating in Niger Delta, Nigeria. Sample comprised oil and gas firms operating in Port Harcourt, Rivers State, being the capital of the Niger Delta States [21]. The study employed survey method of data collection. Convenience and snowball sampling methods were utilized since access to businesses proved difficulty using a probability sampling method. 150 questionnaires were administered and out of that, 24 were either badly filled, or could not be returned leaving a total of 126 which signify usable response rate of $84 \%$.

\subsection{Measurement and operationalization of variables}

Instrument for measurement was divided into dependent and independent variables. Dependent variable included organisational effectiveness which was divided into productivity and stability while independent variables comprised Corporate Social Responsibility. Existing scales from relevant literature were adopted and adapted for this study. Similarly, scales from [14] were used to measure organisational effectivenesswhile Corporate Social Responsibility was measured with scales from [12].A five-point Likert scale ranging from Strongly Agree $=5$ to Strongly Disagree $=1$ was used to measure each of the variables. Data analysis was done using SPSS 21. Tools used include descriptive statistics and multiple regression. Descriptive statistics was used to find out the demographic configuration of the respondents while multiple regression was used to test hypotheses.

\section{Results}

Validity and reliability tests were conducted on the scales used for measurement. Below is the table showing the test result.

Table 1: Reliability test for Cronbach's Alpha

\begin{tabular}{lcc}
\hline \multicolumn{1}{c}{ Variable } & Number of items & Cronbach's Alpha \\
\hline Productivity & 4 & 0.710 \\
Stability & 3 & 0.726 \\
Corporate Social Responsibility (CSR) & 4 & 0.812 \\
\hline
\end{tabular}

Table 2: Descriptive Statistics for demographics

\begin{tabular}{|c|c|c|c|}
\hline \multicolumn{2}{|c|}{ Demographics } & \multirow{2}{*}{$\begin{array}{c}\text { Frequency } \\
41\end{array}$} & \multirow{2}{*}{$\begin{array}{c}\begin{array}{c}\text { Valid Frequency } \\
\text { Percent }(\%)\end{array} \\
32.5\end{array}$} \\
\hline No. of employees & $1-10$ & & \\
\hline & $11-20$ & 37 & 29.4 \\
\hline & $21-30$ & 19 & 15.1 \\
\hline & $31-40$ & 11 & 8.7 \\
\hline & 41\& Above & 18 & 14.3 \\
\hline \multirow[t]{5}{*}{ Company's Annual Turnover } & $\mathrm{N} 50 \mathrm{~m}-\mathrm{N} 100 \mathrm{~m}$ & 36 & 28.6 \\
\hline & $\mathrm{N} 110 \mathrm{~m}-\mathrm{N} 150 \mathrm{~m}$ & 44 & 34.9 \\
\hline & N160m-N200M & 23 & 18.3 \\
\hline & $\mathrm{N} 210 \mathrm{~m}-\mathrm{N} 250 \mathrm{~m}$ & 3 & 2.4 \\
\hline & N260m \& Above & 20 & 15.9 \\
\hline \multirow[t]{4}{*}{ Business Sector } & Marketing & 82 & 65.1 \\
\hline & Distribution & 24 & 19.0 \\
\hline & Retail & 10 & 7.9 \\
\hline & Exploration & 10 & 7.9 \\
\hline \multirow[t]{4}{*}{ Position in the Firm } & Manager & 58 & 46.0 \\
\hline & Executive Officer & 16 & 12.7 \\
\hline & Sales Officer & 15 & 11.9 \\
\hline & Director & 37 & 29.4 \\
\hline \multirow[t]{2}{*}{ Does your firm engage in CSR } & Yes & 103 & 81.7 \\
\hline & No & 23 & 18.3 \\
\hline
\end{tabular}

Table 3 Correlation of variables

\begin{tabular}{llll}
\hline & 1 & 2 & 3 \\
\hline Productivity & & & \\
Stability & $.69^{*}$ & & \\
CSR & $.57^{*}$ & $.53^{*}$ & \\
\hline
\end{tabular}

$*=$ statistically significant at $p<.05$.

From Table 3, Pearson's correlation indicate thatCorporate Social Responsibility (CSR) were significantly correlated with Productivity and Stability, $r=.57, r=.53$ respectively, while productivity was significantly with stability, $r=.69$ (all $p s<.001)$. 
The first regression analyses were conducted to determine the predictive power of CSR on organisational effectiveness comprising productivity. The assumptions of independence of errors, normality of residuals and Durbin-Watson were all met. From Table 4, Corporate Social Responsibility $(t(124)=7.7, p<.001)$ is significantly related to firm productivity.From the above, hypothesis 1 was supported.

Table 4 Multiple Regression Analysis

\begin{tabular}{lccc}
\hline Variable & $\boldsymbol{B}$ & $\boldsymbol{S E}_{\boldsymbol{B}}$ & $B$ \\
\hline Constant & 1.99 & 0.31 & \\
CSR & 0.57 & .073 & $.57 *$
\end{tabular}

Note: $\overline{\overline{(D V}=\text { Productivity }) ; B}=$ unstandardized regression coefficient; $S E_{B}=$ Standard error of the coefficient; $\beta=$ standardized coefficient; $R^{2}=.28,(p<.001)$.

The second regression analyses were conducted to determine the predictive power of CSR on firm stability. The assumptions of independence of errors, normality of residuals and Durbin-Watson were all met. From Table 5, Corporate Social Responsibility $(t(124)=6.96, p<.001)$ is significantly related to stability. From the above, hypothesis 2 was supported.

Table 5 Multiple Regression Analysis

\begin{tabular}{lccc}
\hline Variable & $\boldsymbol{B}$ & $\boldsymbol{S \boldsymbol { E } _ { \boldsymbol { B } }}$ & $B$ \\
\hline Constant & 1.80 & 0.34 & $.53^{*}$ \\
CSR & 0.56 & 0.08 & \\
\hline
\end{tabular}

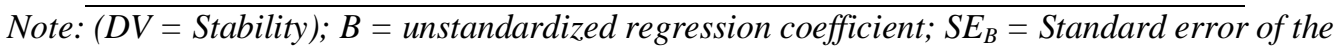
coefficient; $\beta=$ standardized coefficient; $R^{2}=.28,(p<.001)$.

\subsection{Theoretical Implications}

\section{Discussion and Implications}

Experts in the field of CSR have pointed out the role of CSR to organisational effectiveness $[5 ; 18 ; 16]$. Orgganisational productivity was seen to improve as the firm increases its involvement in CSR engagements. Also, from the analysis, the firm's engagement in CSR will have directional effect on its stability. This study corroborates the work of [20]. The firm's productivity and stability are anchored on its involvement in CSR. This is even more evident as awareness and enlightenment increases through the mass media. The firm that shirks from this responsibility is bound to face pressures not only from the government but can be attacked by the host community which may result to operational shutdowns. When shutdowns occur, it will likely affect the firm's productivity.

\subsection{Managerial Implications}

Just as [19] point out, firms with enhanced CSR can gain competitive edge over their rivals with less social presence in their operating environment in ways that reduce cost and increase their market share, improve performance and profitability. Firms should make a paradigm shift from the traditional understanding of CSR as philanthropy and charity and see CSR as a mutually beneficial business strategy. Since organisations stand to gain improved performance with enhanced CSR drive, it is important managers device and develop means of engaging and empowering its host community in order to achieve cordiality in community-company relationships. It is important to point out here that while firms continue in their identification with community activities like Christmas, cultural and social engagements, consideration should be given to mind and mental empowerment such as involvement in scholarship schemes and training in vocational and technical skills.

This will likely reduce such factors that militate against their attainment of the overall business objectives of the firms, improve community social economy and add to the firm's bottom line. This is against the backdrop of continuous rise in youth restiveness and resistance to the operations of oil and gas firms by youths of their host communities despite the claims of huge investments in community welfare and developmental schemes by these firms. The reason is obvious.Empowerment tools in the hands of economically and mentally untrained, undeveloped and minds. Youth and women empowerment schemes should be designed to create capacity that will engender independent entrepreneurial abilities, economic vision, passion and drive for self-accomplishment. Finally, various elements of youth and women developments such as local and foreign scholarships, establishments of small businesses, loans, skills acquisition schemes, etc. become empowerment tools only in the hands of persons whose minds and mental capabilities have been properly trained and developed.

\subsection{Conclusion, limitations and recommendation for future research}

The study looked at the importance of Corporate Social Responsibility towards the effectiveness of the organisation. It revealed that when firms embark on CSR, the firm will enjoy high level of productivity and 
stability. It is therefore imperative to note that oil and gas firms that embark on CSR will rarely experience shutdowns as a result of host community insurrection.

One of the limitations of the study is the measurement of organisational effectiveness. While there are many variables to measure organisational effectiveness, this study adopted and used only two (productivity and stability). Importantly, the measurement scales were adopted from studies in advanced economies. It is likely that using scales developed in the emerging economies might yield a different result. It is therefore recommended that a study should be conducted to measure other dimensions of organisational effectiveness like profitability, market share turnover. A study to develop and validate measurement instruments in the emerging economies is also recommended.

\section{References}

[1]. Amit, K.S., Gayatril, N., Vipul, M. and Shraddha, P. Corporate Social Responsibility: A case study of TATA group, IOSR Journals, 2012,17-27.

[2]. Bhattacharya, C.B. Korschun, D. and Sen, S. Strengthening stakeholder-company relationships through mutually beneficial corporate social responsibility initiatives, Journal of Business Ethics, 85(2), 2009, 257-272.

[3]. Chandler, G. (2001). Defining corporate social responsibility, Ethical Performance Best Practice, fall, Fall.

[4]. Orlitzky, M., Schmidt, F.L., Rynes, S. L. Corporate Social and Financial Performance: A Meta-analysis, Organisation Studies, 24(3), 2003, 403-441

[5]. Asemah, E.S., Okpanachi, R.A. and Edegoh, L.O.N. Business Advantages of Corporate Social Responsibility Practice: A Critical Review, New Media and Mass Communication, 18, 2013, 45-54.

[6]. Cornell, B. and Shapiro, A. Corporate Stakeholders and Corporate finance, Financial Management, 16, 1987, 5-14.

[7]. $\quad$ Freeman, R.E. Strategic Management: A Stakeholder Perspective. (Englewood Cliffs: Prentice Hall, 1984)

[8]. Dane, K.P. The relationship between perceptions of corporate citizenship and organizational commitment, Business and Society, 43(3), 2004, 25-35

[9]. Lee, E.M., Park, S. and Lee, H.J. Employee perception of CSR activities: Its antecedents and consequences, Journal of Business Research, 66, 2013, 1716-1724.

[10]. Cochran, P. L., and Wood, R. A. (1984). Corporate social responsibility and financial performance, Academy of Management Journal, 27(1), 1984, 42-56.

[11]. Fonceca, C and Jebaseelan, A.U.S. Critical appraisal of corporate social responsibility activities in India. IOSR Journal of Humanities and Social Sciences, 4(2), 2012, 45-48.

[12]. Turker, D. Measuring Corporate Social Responsibility: A Scale Development Study, Journal of Business Ethics, 85, 2009, 411-427.

[13]. Du, S., Bhattacharya, C. B. and Sen, S. Maximising business returns to corporate social responsibility (CSR): The role of social responsibility communication, International Journal of Management Reviews, 12(1), 2010, 8-19.

[14]. Eydi, H. Confirmatory Factor Analysis of the Sport Organisational Effectiveness Scale According Competing Value Framework, Universal Journal of Management, 1(2), 2013, 83-92.

[15]. Cegarra-Navarro, J. and Martinez-Martinez, A. Linking Corporate Social Responsibility with administration through organizational outcomes, Social Responsibility Journal, 5(4), 2009, 499-511.

[16]. Bauman, C.W. and Skitka, L.J. Corporate social responsibility as a source of employee satisfaction, Research in OrganisationalBehaviour, 32, 2012, 63-86.

[17]. Bhattacharya, S., Sahay, A., Arora, A. and Chaturvedi, A. A toolkit for designing firm level strategic CSR initiatives, Social Responsibility Journal, 4(3). 2008, 265-282.

[18]. Costa, R. and Menichini, T. (2013). A multidimensional approach for CSR assessment: The importance of stakeholder perception, Expert Systems with Applications, 40(1), 2013, 150-161.

[19]. Ojo, G.U. Community Perception and Oil Companies Corporate Social Responsibility Initiative in the Niger Delta, Studies in Sociology of Science, 3(4), 2012, 11-21.

[20]. Lee, Y.K., Kim,Y.S., Lee, K.H. and Li, D.X. (2012). The impact of CSR on relationship quality and relationship outcomes: A perspective of service employees, International Journal of Hospitality Management,31, 2012, 745-756.

[21]. Omubo-Pepple, V.B., Briggs-Kamara, M.A. and Tamunobereton-ari, I. Noise Pollution in Port Harcourt Metropolis: Sources, Effects, and Control', Pacific Journal of Science and Technology, 11(2),2010, 592-600. 